\title{
The differences between copper sulfate and tribasic copper chloride on growth performance, redox status, deposition in tissues of pigs, and excretion in feces
}

\author{
Ping Zheng', Bei Pu', Bing Yu', Jun ${ }^{1}{ }^{1}$, Jie $\mathrm{Yu}^{1}$, Xiangbing Mao', Yuheng Luo', Junqiu Luo', \\ Zhiqing Huang ${ }^{1}$, Chenggui Luo ${ }^{2}$, Shaohui Wang ${ }^{2}$, and Daiwen Chen ${ }^{1, *}$
}

\author{
* Corresponding Author: Daiwen Chen \\ Tel: +86-0835-2882088, Fax: +86-0835-2882088, \\ E-mail: dwchen@sicau.edu.cn \\ ${ }^{1}$ Institute of Animal Nutrition, Sichuan Agricultural \\ University, Key Laboratory of Animal Disease- \\ Resistance Nutrition, Ministry of Education, Ya'an \\ 625014, China \\ ${ }^{2}$ Chengdu Shuxing Feed Co. Ltd. Chengdu 610043, \\ China \\ ORCID \\ Ping Zheng \\ https://orcid.org/0000-0002-2508-762X \\ Bei Pu \\ https://orcid.org/0000-0001-8891-0284 \\ Bing Yu \\ https://orcid.org/0000-0002-6889-7972 \\ Jun He \\ https://orcid.org/0000-0003-4264-2477 \\ Jie Yu \\ https://orcid.org/0000-0002-6768-7236 \\ Xiangbing Mao \\ https://orcid.org/0000-0002-6292-7747 \\ Yuheng Luo \\ https://orcid.org/0000-0002-2333-1457 \\ Junqiu Luo \\ https://orcid.org/0000-0002-1024-1866 \\ Zhiqing Huang \\ https://orcid.org/0000-0001-5092-9297 \\ Chenggui Luo \\ https://orcid.org/0000-0001-8909-6931 \\ Shaohui Wang \\ https://orcid.org/0000-0002-4703-6743 \\ Daiwen Chen \\ https://orcid.org/0000-0002-8351-7421
}

Submitted Jul 10, 2017; Revised Aug 24, 2017; Accepted Nov 30, 2017
Objective: The objective of this experiment was to compare the effects of adding $130 \mathrm{mg} / \mathrm{kg}$ $\mathrm{Cu}$ from either copper sulfate (CS) or tribasic copper chloride (TBCC) on growth performance, mineral deposition in tissues, and the excretion in feces of pigs as well as changes in the mineral contents in tissues and feces when the supplemental $\mathrm{Cu}$ level was decreased from 130 $\mathrm{mg} / \mathrm{kg}$ to $10 \mathrm{mg} / \mathrm{kg}$.

Methods: A total of 72 pigs $(32.6 \pm 1.2 \mathrm{~kg})$ were randomly assigned to a CS diet or a TBCC diet with 6 pens per treatment. The trial lasted $102 \mathrm{~d}$ and included 3 phases (phase 1,1 to 30 d; phase 2, 31 to $81 \mathrm{~d}$; and phase 3, 82 to $102 \mathrm{~d}$ ). The supplemental levels of $\mathrm{Cu}$ in the 2 treatments were $130 \mathrm{mg} / \mathrm{kg}$ in phase 1 and 2 and $10 \mathrm{mg} / \mathrm{kg}$ in phase 3 .

Results: The results showed that pigs fed the CS diet tended to have higher average daily gain than pigs fed the TBCC diet during $\mathrm{d} 1$ to $81(\mathrm{p}<0.10)$. Compared with CS, TBCC increased the activities of aspartate transaminase (AST), ceruloplasmin, and superoxide dismutase in serum on $\mathrm{d} 30(\mathrm{p}<0.05)$. The TBCC decreased the Cu level in the liver on $\mathrm{d} 81(\mathrm{p}<0.05)$ and increased the Mn level in the liver on $\mathrm{d} 102(\mathrm{p}<0.05)$. The concentration of $\mathrm{Cu}$ in feces sharply decreased when the supplemental Cu level in diet changed from $130 \mathrm{mg} / \mathrm{kg}$ to $10 \mathrm{mg} / \mathrm{kg}$ in both diets $(\mathrm{p}<0.05)$.

Conclusion: The result suggested that TBCC and CS had no significant difference on growth performance but TBCC had higher activities of AST and antioxidant enzymes and lower liver $\mathrm{Cu}$ than CS when pigs fed diets with $130 \mathrm{mg} \mathrm{Cu} / \mathrm{kg}$ diet.

Keywords: Copper Sulfate; Deposition; Excretion; Growth Performance; Pigs; Tribasic Copper Chloride

\section{INTRODUCTION}

Copper is an essential element for swine and plays important roles in many physiological metabolic processes. Dietary Cu levels of 5 to $10 \mathrm{mg} / \mathrm{kg}$ are generally enough to meet the pig's nutrient requirement for these processes according to the NRC [1]. High dietary levels of $\mathrm{Cu}$ (100 to $250 \mathrm{mg} / \mathrm{kg}$ ) have proven to have positive effects on improving growth performance in weanling piglets and were applied to swine production [2,3]. However, longterm supplementation of a high level of $\mathrm{Cu}$ can create a high risk of $\mathrm{Cu}$ accumulation in organs as well as ecological environment, which needs more attention. The maximum permitted level of $\mathrm{Cu}$ in food is $10 \mathrm{mg} / \mathrm{kg}$ according to the hygienic standard for meat products of Chinese Regulation [4]. High levels of $\mathrm{Cu}$ accumulation in organs will harm human's health because most people in China have the habit of using the organs of pigs as food, especially liver and kidney. Furthermore, a high level of $\mathrm{Cu}$ would influence the metabolism of 
other minerals by the interaction of $\mathrm{Cu}$ with other mineral elements.

The most common form of $\mathrm{Cu}$ used in feeds for growth promotion in pigs is copper sulfate (CS). Tribasic copper chloride (TBCC) is a less reactive and less destructive form of $\mathrm{Cu}$ due to its low hygroscopicity when combined with vitamins in base mixes, supplements, and diets. In vitro digestion assay showed that the solubility of $\mathrm{Cu}$ was not different between the sources [5]. Previous research indicated that TBCC could improve growth performance during early and late finishing [2] but that CS had no growth promoting benefit during finishing periods [6]. At the same time, data is limited about the effects of CS and TBCC on minerals deposition in tissues and excretion in feces. Therefore, the objective of this experiment was to compare the effects of adding $130 \mathrm{mg} / \mathrm{kg} \mathrm{Cu}$ from either CS or TBCC on growth performance, trace mineral deposition in tissues, and the excretion in feces of pigs as well as changes in the mineral contents in tissues and feces when the supplemental $\mathrm{Cu}$ level was decreased from $130 \mathrm{mg} / \mathrm{kg}$ to $10 \mathrm{mg} / \mathrm{kg}$.

\section{MATERIALS AND METHODS}

\section{Animal care}

The experimental protocol used in the following experiment was reviewed and approved by the Animal Experimental Committee of Sichuan Agricultural University. This experiment was conducted at the Animal Experiment Center of Chengdu Shuxing Feed Co. Ltd. Copper sulfate and TBCC were provided by Chengdu Shuxing Feed Co. Ltd. (Chengdu, China).

\section{Experimental design and animal management}

A total of 72 crossbred Duroc $\times$ Landrace $\times$ Yorkshire pigs $(70 \pm 1$ $\mathrm{d}$ and $32.6 \pm 1.2 \mathrm{~kg}$ ) were assigned to the CS diet or the TBCC diet with 6 replicate pens per treatment and six pigs per pen ( 3 barrows and 3 gilts per pen) in a randomized complete block design according to initial body weight (BW) and gender. The trial lasted $102 \mathrm{~d}$ and included 3 phases (phase 1, 30 to $50 \mathrm{~kg}$ [ 1 to $30 \mathrm{~d}$ ]; phase 2, 50 to $100 \mathrm{~kg}$ [ 31 to $81 \mathrm{~d}$ ]; and phase 3,100 to $110 \mathrm{~kg}$ [ 82 to $102 \mathrm{~d}$ ]). The concentrations of supplemental $\mathrm{Cu}$ in the 2 treatments were $130 \mathrm{mg} / \mathrm{kg}$ in phase 1 and 2 and $10 \mathrm{mg} / \mathrm{kg}$ in phase 3. The basal diets were formulated to meet or exceed NRC nutrient recommendations [1]. Ingredient compositions of the basal diets are presented in Table 1. Before the experiment, all pigs were fed corn-soybean diet supplementation with $6 \mathrm{mg} / \mathrm{kg}$ CS. All pigs were housed in a temperaturecontrolled room with continuous lighting. Each pen ( 4 by 3 $\mathrm{m})$ was equipped with a 1-sided feeder and a stainless-steel nipple drinker to allow the pig ad libitum access to feed and water. All pigs were individually weighed at the beginning of experiment and the end of each phase after $12 \mathrm{~h}$ of fasting, and
Table 1. Ingredients and nutrient compositions of basal diets (DM basis)

\begin{tabular}{|c|c|c|}
\hline Item & Phase $1^{1)}$ & Phases 2 and $3^{1)}$ \\
\hline \multicolumn{3}{|l|}{ Ingredients (\%) } \\
\hline Corn & 69.71 & 73.62 \\
\hline Wheat bran & 5.00 & 6.30 \\
\hline Soybean meal & 19.00 & 16.00 \\
\hline Fish meal & 2.00 & 0.00 \\
\hline Monocalcium phosphate & 0.80 & 0.70 \\
\hline Limestone & 0.90 & 0.90 \\
\hline Soybean oil & 1.80 & 1.80 \\
\hline L-lysine $\mathrm{HCl}$ & 0.15 & 0.04 \\
\hline Salt & 0.30 & 0.30 \\
\hline Trace mineral premix $x^{2)}$ & 0.20 & 0.20 \\
\hline Vitamin premix ${ }^{3)}$ & 0.04 & 0.04 \\
\hline Choline chloride & 0.10 & 0.10 \\
\hline \multicolumn{3}{|l|}{ Nutrients composition } \\
\hline$D E^{4)}($ Mcal/kg) & 13.97 & 13.97 \\
\hline$C P^{5)}(\%)$ & 15.56 & 13.30 \\
\hline $\mathrm{Ca}^{5}(\%)$ & 0.67 & 0.55 \\
\hline Total $P^{5)}(\%)$ & 0.54 & 0.42 \\
\hline Available $\mathrm{P}^{4)}(\%)$ & 0.33 & 0.26 \\
\hline Digestible Lys ${ }^{4)}(\%)$ & 0.92 & 0.66 \\
\hline Digestible Met+Cys ${ }^{4)}(\%)$ & 0.58 & 0.44 \\
\hline Digestible Thr) (\%) & 0.60 & 0.51 \\
\hline Digestible Trp ${ }^{4)}(\%)$ & 0.17 & 0.15 \\
\hline
\end{tabular}

$\mathrm{DM}$, dry matter; $\mathrm{DE}$, digestible energy; $\mathrm{CP}$, crude protein; $\mathrm{Ca}$, calcium; $\mathrm{P}$, phosphorus; Lys, lysine; Met, methionine; Cys, cystine; Thr, threonine; Trp, tryptophan.

1) Body weight range and the duration of phase 1, phase 2, and phase 3 were 30 to $50 \mathrm{~kg}$ (d1 to 30), 50 to $100 \mathrm{~kg}$ (d 31to 81), and 100 to $115 \mathrm{~kg}$ (d 82 to 102), respectively.

${ }^{2)}$ Mineral premix provided the following amounts per $\mathrm{kg}$ complete diet: $120 \mathrm{mg}$ $\mathrm{Fe}\left(\mathrm{FeSO}_{4} \cdot 7 \mathrm{H}_{2} \mathrm{O}\right), 120 \mathrm{mg} \mathrm{Zn}\left(\mathrm{ZnSO}_{4} \cdot 7 \mathrm{H}_{2} \mathrm{O}\right), 20 \mathrm{mg} \mathrm{Mn}\left(\mathrm{MnSO}_{4} \cdot \mathrm{H}_{2} \mathrm{O}\right), 0.3 \mathrm{mg} \mathrm{Se}$ $\left(\mathrm{Na}_{2} \mathrm{SeO}_{3} \cdot 5 \mathrm{H}_{2} \mathrm{O}\right)$, and $0.3 \mathrm{mg} \mathrm{I}(\mathrm{KI})$.

${ }^{3)}$ Vitamin premix provided the following amounts per kg complet diet: 2,000 IU vitamin $A_{1}, 360$ IU vitamin $D_{3}, 16 \mathrm{mg}$ vitamin $E_{1} 1 \mathrm{mg}$ vitamin $\mathrm{K}_{3}, 4 \mathrm{mg}$ vitamin $B_{1}$, $1 \mathrm{mg}$ vitamin $B_{2}, 1.4 \mathrm{mg}$ vitamin $B_{6}, 0.04 \mathrm{mg}$ vitamin $B_{12}, 0.5 \mathrm{mg}$ folic acid, $4 \mathrm{mg}$ niacin, $22 \mathrm{mg}$ D-pantothenic acid, and $0.1 \mathrm{mg}$ biotin.

4) Means calculated values.

${ }^{5)}$ Means analyzed values.

feed intake per pen was recorded daily throughout the experiment to calculate average daily gain (ADG), average daily feed intake, and gain/feed.

\section{Sample collection}

Representative feed samples of each dietary treatment were collected for chemical analysis. Approximately $200 \mathrm{~g}$ of feed samples from each diet were dried at $65^{\circ} \mathrm{C}$ for $48 \mathrm{~h}$ and subsequently ground to pass through a $1-\mathrm{mm}$ screen. All feed samples were analyzed for $\mathrm{CP}, \mathrm{Ca}$, and $\mathrm{P}$ according to official methods of analysis of AOAC [7].

At the end of phase 1 and phase 2 of the experiment, blood samples were collected into glass tubes without anticoagulant by jugular venipuncture from one selected male pig with BW closet to average $\mathrm{BW}$ in each pen. After centrifugation $(3,000 \times \mathrm{g}$ for $15 \mathrm{~min}$ at $4^{\circ} \mathrm{C}$ ), serum samples were collected and stored 
at $-20^{\circ} \mathrm{C}$ until analysis.

On $\mathrm{d} 0,3,7,14$, and 21 of phase 3 , fresh fecal samples were randomly collected from at least 2 pigs in each pen twice in a day. The fresh fecal samples were marked with pen number and date and then stored at $-20^{\circ} \mathrm{C}$ before drying. Approximately $200-\mathrm{g}$ fecal samples from each pen were dried at $65^{\circ} \mathrm{C}$ for $48 \mathrm{~h}$ and subsequently ground to pass through a 1-mm screen and stored in plastic bags at $-20^{\circ} \mathrm{C}$ until analysis.

At the end of phase 2 and phase 3 , one male pig with BW close to average BW in each pen was chosen to sample. Pigs were anesthetized by electric shock and then euthanized by exsanguination. The abdomen was immediately opened for the collection of liver, kidney, and longissimus dorsi muscle samples. Before analysis, samples were stored at $-20^{\circ} \mathrm{C}$.

\section{Serum physiochemical parameters}

Serum total protein, albumin, urea, aspartate transaminase (AST), and alanine transaminase (ALT) were measured by the UV method using an automatic biochemistry analyzer (Hitachi 7020; Hitachi, Ltd., Chiyoda, Tokyo, Japan).

\section{Measurement of enzyme activities}

The activities of glutathione peroxidase (GPx), superoxide dismutase (SOD) and ceruloplasmin in serum were measured by assay kits from Nanjing Jiancheng Bioengineering Institute (Nanjing, China). The methods were according to the manufacturer's instructions. All samples were measured in duplicate.

\section{Copper, Fe, Mn, and $\mathrm{Zn}$ concentrations}

The contents of $\mathrm{Cu}$ in serum and $\mathrm{Cu}, \mathrm{Fe}, \mathrm{Mn}$, and $\mathrm{Zn}$ in liver, kidney, muscle, and feces were measured by atomic absorption spectrometry (GGX-6, Bejing Kechuang Haiguang instrument Co. Ltd., Beijing, China). The tissue and feces samples were prepared for mineral elements analysis by wet ashing using nitric acid and perchloric acid [8]. Before analysis, samples were dried overnight at $105^{\circ} \mathrm{C}$. Approximately $2.0 \mathrm{~g}$ of tissues and feces were obtained from each sample for this purpose. The concentrations of trace minerals in tissues and feces are expressed as milligrams per kilogram of dry matter (DM).

\section{Statistical analysis}

Replicate pen was considered the experimental unit for all analysis $(n=6)$. Data were analyzed by using independent sample $t$ test comparisons and by 1-way analysis of variance for the different time points of mineral contents in feces within each type of diet. The results were presented as means and standard error of the mean. For significance determination, the $\alpha$-level was set as 0.05 . Possibility value $\leq 0.05$ indicated significant difference, and values between 0.05 and 0.1 indicate a trend. All statistical analysis was performed using SPSS 19.0 (IBM, Armonk, NY, USA).
Table 2. Effects of copper sulfate (CS) and tribasic copper chloride (TBCC) on the growth performance in pigs

\begin{tabular}{lccc}
\hline Item & CS & TBCC & p-value \\
\hline BW (kg) & & & \\
d 1 & $32.82 \pm 0.32$ & $32.44 \pm 0.60$ & 0.944 \\
d 30 & $50.75 \pm 0.92$ & $49.62 \pm 1.07$ & 0.440 \\
d 81 & $98.42 \pm 2.24$ & $93.52 \pm 1.86$ & 0.123 \\
d 102 & $115.38 \pm 2.68$ & $109.56 \pm 3.18$ & 0.166 \\
d 1 to 30 & & & \\
ADG (kg) & $0.60 \pm 0.02$ & $0.58 \pm 0.02$ & 0.591 \\
ADFI (kg) & $1.55 \pm 0.02$ & $1.47 \pm 0.03$ & 0.144 \\
G/F & $0.41 \pm 0.011$ & $0.39 \pm 0.016$ & 0.300 \\
d 31 to 81 & & & \\
ADG (kg) & $0.93 \pm 0.03$ & $0.86 \pm 0.03$ & 0.106 \\
ADFI (kg) & $2.78 \pm 0.09$ & $2.65 \pm 0.08$ & 0.338 \\
G/F & $0.34 \pm 0.003$ & $0.33 \pm 0.008$ & 0.309 \\
d 1 to 81 & & & \\
ADG (kg) & $0.81 \pm 0.02$ & $0.76 \pm 0.02$ & 0.083 \\
ADFI (kg) & $2.32 \pm 0.15$ & $2.21 \pm 0.11$ & 0.196 \\
G/F & $0.35 \pm 0.003$ & $0.34 \pm 0.006$ & 0.611 \\
d 82 to 102 & & & \\
ADG (kg) & $1.03 \pm 0.08$ & $0.94 \pm 0.05$ & 0.165 \\
ADFI (kg) & $3.07 \pm 0.08$ & $2.95 \pm 0.07$ & 0.347 \\
G/F & $0.36 \pm 0.022$ & $0.33 \pm 0.011$ & 0.183 \\
\hline ADG the avage & &
\end{tabular}

$A D G$, the average daily gain; $A D F I$, the average daily feed intake; $G / F$, gain/feed.

\section{RESULTS}

\section{Growth performance}

The effects of CS and TBCC on growth performance of pigs are summarized in Table 2 . There were no significant differences between the CS and TBCC diets for growth performance, but there was a tendency for decreased ADG during $\mathrm{d} 1$ to 81 in pigs fed the TBCC diet compared with pigs fed the CS diet

Table 3. Effect of copper sulfate (CS) and tribasic copper chloride (TBCC) on the physiochemical parameters and Cu concentration in serum of pigs

\begin{tabular}{lrcc}
\hline Item & \multicolumn{1}{c}{ CS } & TBCC & p-value \\
\hline $\mathrm{d} 30$ & & & \\
TP (g/L) & $57.55 \pm 0.89$ & $59.88 \pm 1.10$ & 0.131 \\
ALB (g/L) & $27.5 \pm 0.65$ & $29.23 \pm 1.22$ & 0.237 \\
AST (units/L) & $40.33 \pm 2.09$ & $51.50 \pm 3.47$ & 0.020 \\
ALT (units/L) & $48.33 \pm 2.81$ & $50.17 \pm 3.53$ & 0.693 \\
Urea (mmol/L) & $2.68 \pm 0.18$ & $3.15 \pm 0.22$ & 0.129 \\
Cu ( $\mu \mathrm{g} / \mathrm{mL})$ & $2.03 \pm 0.17$ & $2.26 \pm 0.13$ & 0.333 \\
d 81 & & & \\
TP (g/L) & $59.5 \pm 0.91$ & $59.87 \pm 2.32$ & 0.886 \\
ALB (g/L) & $30.82 \pm 0.61$ & $29.67 \pm 0.44$ & 0.161 \\
AST (units/L) & $34.5 \pm 2.38$ & $40.67 \pm 3.46$ & 0.173 \\
ALT (units/L) & $42.50 \pm 1.26$ & $48.67 \pm 2.58$ & 0.067 \\
Urea (mmol/L) & $3.72 \pm 0.26$ & $4.36 \pm 0.25$ & 0.107 \\
Cu ( $\mu \mathrm{g} / \mathrm{mL})$ & $2.03 \pm 0.24$ & $2.26 \pm 0.15$ & 0.333 \\
\hline
\end{tabular}

TP, total protein; ALB, albumin; AST, aspartate transaminase; ALT, alanine transaminase. 
$(\mathrm{p}<0.10)$

Physiochemical parameters and Cu concentration in serum On d 30, serum total protein, albumin, urea, and ALT were not affected by $\mathrm{Cu}$ sources, but activities of serum AST in pigs fed the TBCC diet were higher than that in pigs fed the CS $\operatorname{diet}(\mathrm{p}<0.05$; Table 3$)$. On $\mathrm{d} 81$, serum total protein, albumin, urea, and AST were not different between pigs fed the CS diet and TBCC diet, but the activities of serum ALT in pigs fed the TBCC diet trended to higher than that in pigs fed the CS diet $(\mathrm{p}<0.1)$. Data on the concentrations of $\mathrm{Cu}$ in serum are shown in Table 3. There were no differences in the levels of $\mathrm{Cu}$ in serum between the CS and TBCC treatments.

\section{Serum antioxidant enzyme activities}

As shown in Figure 1, TBCC significantly increased the activities of ceruloplasmin and SOD in serum compared with CS on $\mathrm{d} 30(\mathrm{p}<0.05)$. There was a tendency for increased activity of SOD in pigs fed the TBCC diet compared with pigs fed the $\mathrm{CS}$ diet on $\mathrm{d} 81(\mathrm{p}<0.1)$. However, there was no difference between the TBCC diet and the CS diet for the activity of GPx.

\section{Copper, $\mathrm{Fe}, \mathrm{Zn}$, and $\mathrm{Mn}$ concentrations in tissues}

Data for $\mathrm{Cu}, \mathrm{Fe}, \mathrm{Zn}$, and $\mathrm{Mn}$ concentrations in tissues when supplementing the CS or TBCC diet with $130 \mathrm{mg} / \mathrm{kg} \mathrm{Cu}$ for $81 \mathrm{~d}$ are presented in Table 4 . Copper level were 20 to $40 \mathrm{mg} / \mathrm{kg}$ in liver and kidney and less than $10 \mathrm{mg} / \mathrm{kg}$ in muscle in both $\mathrm{CS}$ and TBCC treatments on $\mathrm{d} 81$. The TBCC produced a significantly lower $\mathrm{Cu}$ level in the liver on $\mathrm{d} 81$ compared with $\mathrm{CS}(\mathrm{p}<0.05)$. No significant differences in $\mathrm{Cu}$ deposition in the kidney and muscle were observed between CS and TBCC. The $\mathrm{Cu}$ sources had no effects on the concentrations of $\mathrm{Fe}, \mathrm{Mn}$, and $\mathrm{Zn}$ in the liver, kidney, and muscle on $\mathrm{d} 81$.

On $\mathrm{d} 102$, when the supplementation level of $\mathrm{Cu}$ was decreased to $10 \mathrm{mg} / \mathrm{kg}$ for $21 \mathrm{~d}$, TBCC increased Mn level in the liver ( $\mathrm{p}<0.05$; Table 5). No significant differences in $\mathrm{Cu}$ deposition in the liver, kidney, and muscle were observed between $\mathrm{CS}$ and TBCC. The $\mathrm{Cu}$ sources had no significant effect on $\mathrm{Fe}$ and $\mathrm{Zn}$ deposition in the liver, kidney, and muscle on $\mathrm{d} 102$.

\section{Copper, $\mathrm{Fe}, \mathrm{Zn}$, and $\mathrm{Mn}$ concentrations in feces}

The concentrations of $\mathrm{Cu}$ in diets significantly influenced the level of $\mathrm{Cu}$ in feces (Figure 2). The concentrations of $\mathrm{Cu}$ in feces sharply decreased when the supplemental $\mathrm{Cu}$ level in diet
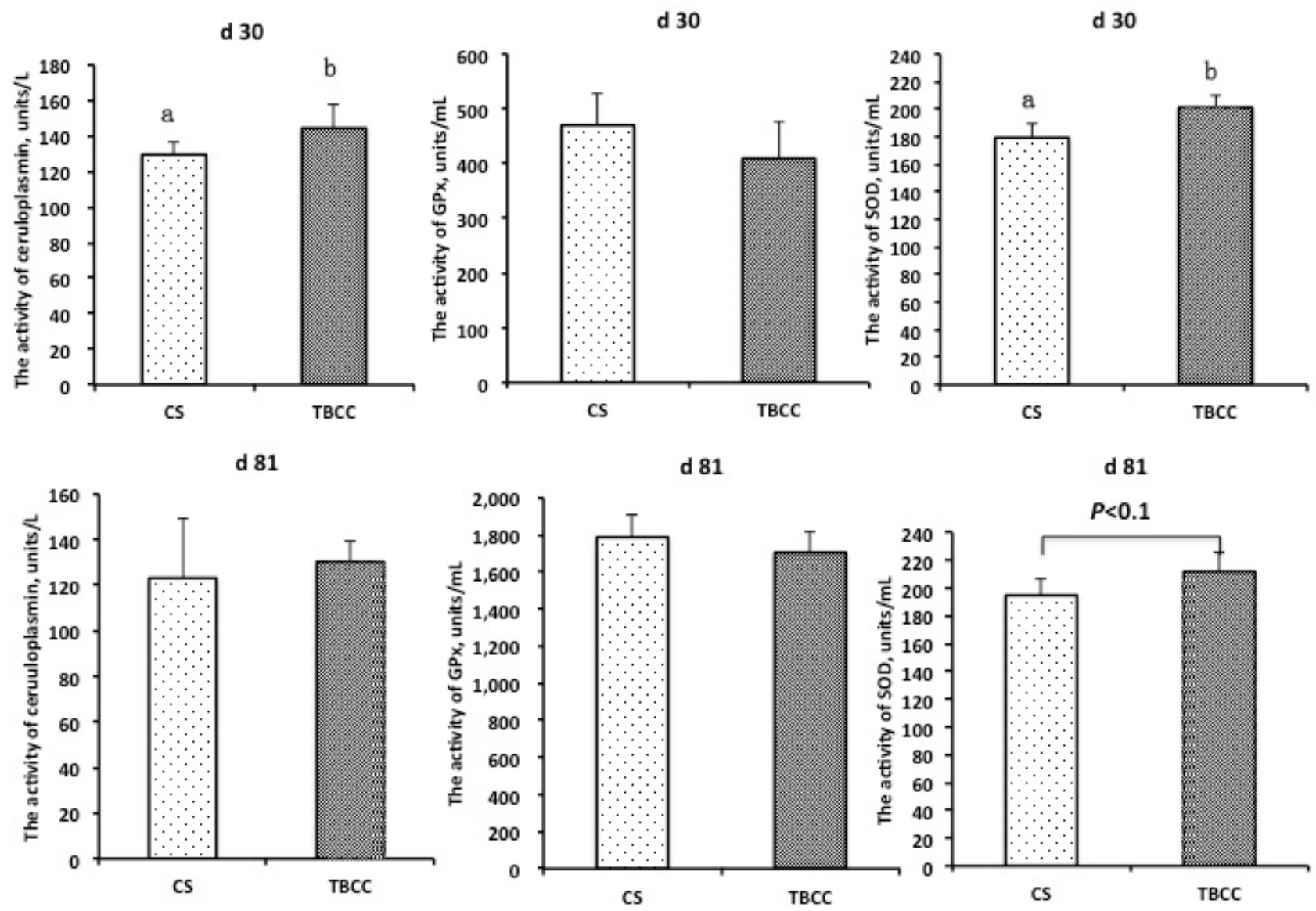

Figure 1. Effect of copper sulfate (CS) and tribasic copper chloride (TBCC) on serum activities of ceruloplasmin, glutathione peroxidase (GPX), and superoxide dismutase (SOD) in pigs. ${ }^{a, b}$ Means with different superscript letters represent differences between the CS diet and the TBCC diet $(p<0.05)$. 
Table 4. Effects of copper sulfate (CS) and tribasic copper chloride (TBCC) on the concentration of $\mathrm{Cu}, \mathrm{Fe}, \mathrm{Zn}$, and $\mathrm{Mn}$ in tissues on $\mathrm{d} 81$ (mg/kg dry matter)

\begin{tabular}{cccc}
\hline Item & CS & TBCC & p-value \\
\hline Liver & & & \\
Cu & $34.88 \pm 1.65$ & $24.36 \pm 1.32$ & 0.006 \\
$\mathrm{Fe}$ & $353.04 \pm 17.55$ & $366.95 \pm 73.73$ & 0.859 \\
$\mathrm{Zn}$ & $335.73 \pm 41.88$ & $310.24 \pm 36.96$ & 0.658 \\
$\mathrm{Mn}$ & $6.85 \pm 0.46$ & $6.83 \pm 0.41$ & 0.982 \\
Kidney & & & \\
$\mathrm{Cu}$ & $33.48 \pm 3.81$ & $31.00 \pm 3.34$ & 0.643 \\
$\mathrm{Fe}$ & $174.17 \pm 35.76$ & $160.99 \pm 4.92$ & 0.626 \\
$\mathrm{Zn}$ & $232.15 \pm 24.13$ & $216.02 \pm 17.12$ & 0.598 \\
$\mathrm{Mn}$ & $4.07 \pm 0.09$ & $4.47 \pm 0.29$ & 0.217 \\
$\mathrm{Muscle}$ & & & \\
$\mathrm{Cu}$ & $7.05 \pm 0.65$ & $6.60 \pm 1.08$ & 0.709 \\
$\mathrm{Fe}$ & $43.59 \pm 3.42$ & $43.71 \pm 4.07$ & 0.982 \\
$\mathrm{Zn}$ & $76.94 \pm 7.13$ & $69.71 \pm 6.29$ & 0.465 \\
$\mathrm{Mn}$ & $0.51 \pm 0.06$ & $0.48 \pm 0.02$ & 0.730 \\
\hline
\end{tabular}

changed from $130 \mathrm{mg} / \mathrm{kg}$ to $10 \mathrm{mg} / \mathrm{kg}(\mathrm{p}<0.05)$. The sources of $\mathrm{Cu}$ in the diet also influenced the level of $\mathrm{Cu}$ in feces on $\mathrm{d}$ 7 and 14 after the supplemental $\mathrm{Cu}$ level was changed to 10
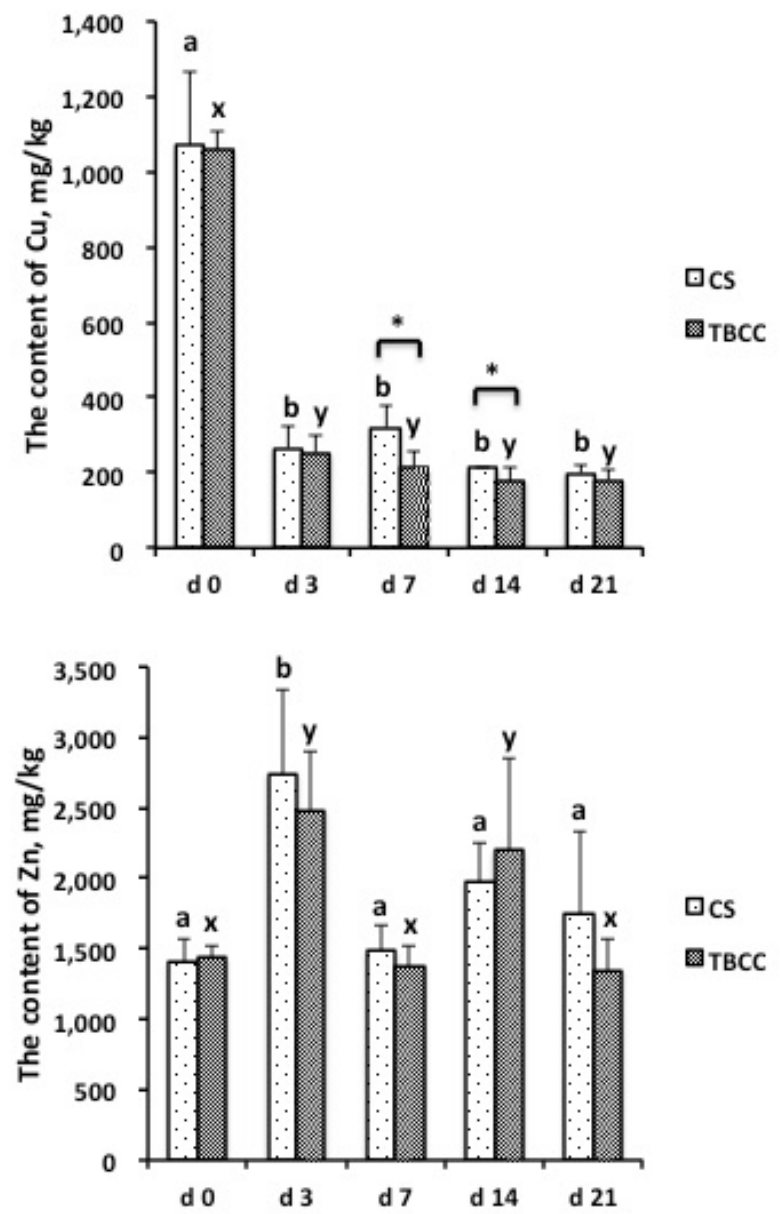

Table 5. Effect of copper sulfate (CS) and tribasic copper chloride (TBCC) on the concentrations of $\mathrm{Cu}$, $\mathrm{Fe}, \mathrm{Zn}$, and $\mathrm{Mn}$ in tissues on d 102 (mg/kg dry matter)

\begin{tabular}{cccc}
\hline Item & CS & TBCC & p-value \\
\hline Liver & & & \\
$\mathrm{Cu}$ & $32.74 \pm 3.67$ & $25.73 \pm 1.08$ & 0.108 \\
$\mathrm{Fe}$ & $246.12 \pm 8.38$ & $257.45 \pm 39.74$ & 0.793 \\
$\mathrm{Zn}$ & $298.54 \pm 30.64$ & $275.52 \pm 24.92$ & 0.576 \\
$\mathrm{Mn}$ & $6.46 \pm 0.02$ & $7.66 \pm 0.27$ & 0.010 \\
Kidney & & & \\
$\mathrm{Cu}$ & $27.34 \pm 2.02$ & $22.89 \pm 3.76$ & 0.297 \\
$\mathrm{Fe}$ & $177.62 \pm 14.33$ & $165.22 \pm 15.65$ & 0.793 \\
$\mathrm{Zn}$ & $213.30 \pm 26.77$ & $204.55 \pm 18.70$ & 0.576 \\
$\mathrm{Mn}$ & $4.83 \pm 0.22$ & $4.84 \pm 0.12$ & 0.957 \\
$\mathrm{Muscle}$ & & & \\
$\mathrm{Cu}$ & $3.88 \pm 0.53$ & $4.77 \pm 0.83$ & 0.456 \\
$\mathrm{Fe}$ & $41.33 \pm 4.98$ & $42.11 \pm 5.29$ & 0.918 \\
$\mathrm{Zn}$ & $80.11 \pm 4.25$ & $74.20 \pm 4.80$ & 0.384 \\
$\mathrm{Mn}$ & $0.47 \pm 0.09$ & $0.47 \pm 0.11$ & 0.958 \\
\hline
\end{tabular}

$\mathrm{mg} / \mathrm{kg}$ with pigs fed TBCC having decreased concentrations of $\mathrm{Cu}$ in feces compared to those fed CS ( $\mathrm{p}<0.05)$.

From Figure 2, we also found that decreasing the level of $\mathrm{Cu}$
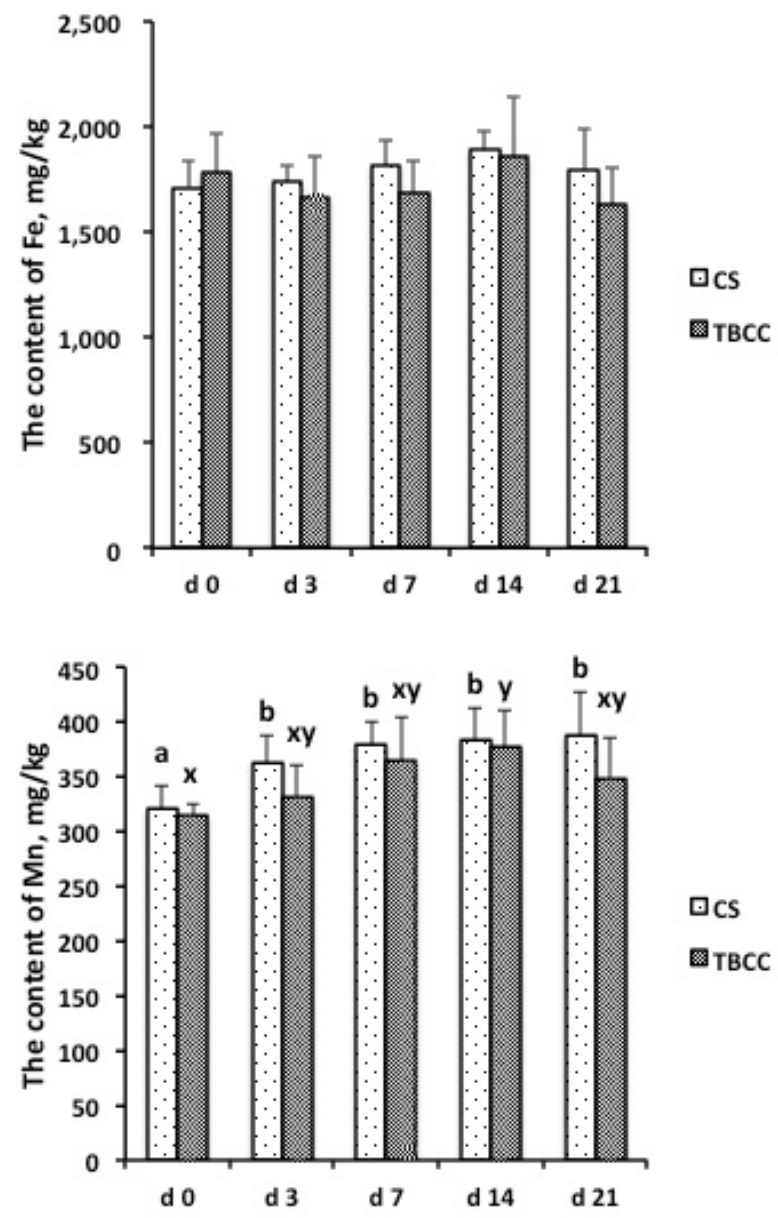

Figure 2. The concentrations of $\mathrm{Cu}, \mathrm{Fe}, \mathrm{Zn}$, and $\mathrm{Mn}$ in feces of pigs when the supplementation Cu level changed from $130 \mathrm{mg} / \mathrm{kg}$ to $10 \mathrm{mg} / \mathrm{kg}$ with the copper sulfate (CS) or tribasic copper chloride (TBCC) diet at d 0,3,7, 14, and 21 (mg/kg dry matter). Means with different superscript letters represent differences between different time points within the CS diet $\left({ }^{(-c}\right)$ or the TBCC diet $\left({ }^{x-2} ; p<0.05\right) .{ }^{*} p<0.05$, CS vS TBCC. 
in the diet increased the concentration of $\mathrm{Zn}$ and $\mathrm{Mn}$ in feces. Compared with $\mathrm{d} 0$, the level of $\mathrm{Zn}$ in feces increased in the CS diet at $\mathrm{d} 3$ as well as the TBCC diet at $\mathrm{d} 3$ and $14(\mathrm{p}<0.05)$. The concentrations of $\mathrm{Mn}$ in feces in the CS treatment were increased at $\mathrm{d} 3,7,14$, and 21 compared with $\mathrm{d} 0(\mathrm{p}<0.05)$. The concentration of $\mathrm{Mn}$ in feces in the TBCC treatment was increased at $\mathrm{d} 14$ compared with $\mathrm{d} 0(\mathrm{p}<0.05)$. There was no difference in the concentrations of $\mathrm{Fe}, \mathrm{Zn}$, and $\mathrm{Mn}$ in feces between the CS diet and the TBCC diet during $\mathrm{d} 0$ to 21 after the supplemental $\mathrm{Cu}$ level was changed from $130 \mathrm{mg} / \mathrm{kg}$ to 10 $\mathrm{mg} / \mathrm{kg}$.

\section{DISCUSSION}

High levels of $\mathrm{Cu}$ are commonly used as growth promoters in the swine industry and its benefits on weight gain and efficiency of feed utilization in both weaned pigs and finishing pigs have been well documented $[3,9]$. The TBCC chloride has been studied as a $\mathrm{Cu}$ source for animal production in pigs. Previous studies reported that TBCC was as effective as CS at improving growth in weanling and finishing pigs [10,11]. In the present study, there was no significant difference on growth performance between pigs fed diets with $130 \mathrm{mg} / \mathrm{kg}$ $\mathrm{Cu}$ from TBCC or CS, but TBCC had a tendency to decrease $\mathrm{ADG}$ of pigs compared with $\mathrm{CS}$ during the first $81 \mathrm{~d}$. However, although the purpose of this study was to investigate the difference of 2 main inorganic copper sources, CS and TBCC, on growth performance, physiochemical parameters, deposition and excretion, it would have been better include a low $\mathrm{Cu}$ diet group in this experiment. In that case, we could have determined the effects of $130 \mathrm{mg} / \mathrm{kg} \mathrm{Cu}$ on growth performance of growing-finishing pigs.

The AST and ALT are 2 important transaminase enzymes, and their concentrations in serum are commonly measured as a part of a diagnostic evaluation of liver function [12]. When hepatic cells are damaged or cell membrane permeability increased, ALT and AST in the liver permeates into the blood, which results in an increase of these enzymes' activity in serum [13]. Previous research reported that the concentrations of AST and ALT in the plasma of rats were significantly elevated by dietary $\mathrm{Cu}$ overload [14]. Pu et al [15] showed that the concentrations of AST and ALT in serum of finishing pigs, when fed a diet with NRC level of CS, were 5.87 and $10.20 \mathrm{U} / \mathrm{L}$, respectively. Compared with Pu's results, our study showed that $130 \mathrm{mg} / \mathrm{kg} \mathrm{Cu}$, whether sourced from CS or TBCC, significantly increased serum concentrations of AST and ALT. At the same time, we measured the main antioxidant enzymes GPx, SOD, and ceruloplasmin in serum and found that TBCC significantly increased the activity of SOD and ceruloplasmin in serum on d 30 compared with CS. Ceruloplasmin is not only the transport protein, which is responsible for carrying $\mathrm{Cu}$ to tissues that need the mineral, and an enzyme catalyzing the oxidation of minerals but also an important extracellular antioxidant and free radical scavenger [16]. Chronic Cu overload could initiate oxidative stress [17]. The enhancement of the activities of antioxidant enzymes could be the results of mitigating oxidative tissue damage [18]. Another study showed that oxidative stress was always coupled with higher serum AST and ALT levels [19]. In this study, pigs fed the TBCC diet with $130 \mathrm{mg} / \mathrm{kg} \mathrm{Cu}$ for $30 \mathrm{~d}$ had higher levels of AST as well as SOD and ceruloplasmin than CS diet, which might indicate that TBCC diet caused more oxidative stress than CS diet. However, the result was inconsistent with previous result that TBCC might cause less oxidative stress in duodenum of weanling pigs than CS when fed at $225 \mathrm{mg} \mathrm{Cu} / \mathrm{kg}$ diet for $11 / 12 \mathrm{~d}$ [20]. The possible reasons could be the difference of pigs' age, the length of feeding time and the level of dietary $\mathrm{Cu}$.

Previous studies reported that liver $\mathrm{Cu}$ concentrations linearly increased with the increase of $\mathrm{Cu}$ concentrations in both TBCC and CS diets [21]. From the results of this experiment, we observed that the concentration of $\mathrm{Cu}$ in the liver and kidney were 2 to 3 times higher than $10 \mathrm{mg} / \mathrm{kg}$, which is the maximum permitted level of $\mathrm{Cu}$ in food according to the hygienic standard for meat products of Chinese Regulation [4], after long-term supplementation with $130 \mathrm{mg} / \mathrm{kg}$ dietary $\mathrm{Cu}$ from both TBCC and CS treatments. Furthermore, decreasing the supplementation level of $\mathrm{Cu}$ in both TBCC and CS diets to $10 \mathrm{mg} / \mathrm{kg}$ for $21 \mathrm{~d}$ still did not decrease the content of $\mathrm{Cu}$ in organs to less than $10 \mathrm{mg} / \mathrm{kg}$. In this study, we also found that liver $\mathrm{Cu}$ was significantly higher in CS pigs than TBCC pigs when fed at $130 \mathrm{mg} \mathrm{Cu} / \mathrm{kg}$ diet. This result agreed with previous result that TBCC diet significantly decreased the concentration of $\mathrm{Cu}$ in the liver of weanling pigs when fed at 225 $\mathrm{mg} \mathrm{Cu} / \mathrm{kg}$ diet [22].

Copper is known to react with a variety of nutrients, and the interactions of microelements are very complicated and can affect the absorption and bioavailability of other nutrients. Previous research indicated that $\mathrm{Fe}, \mathrm{Cu}$, and $\mathrm{Zn}$ affected the uptake of one another by possible competitive inhibition of transport and bioavailability [23]. Copper and Mn are the important components of SOD [24]. In this study, we also found that TBCC significantly increased $\mathrm{Mn}$ concentration in the liver compared with CS. The possible mechanism may be competitive binding to the divalent metal transporter 1 protein, which participates in divalent metal transport $(\mathrm{Fe}, \mathrm{Cu}$, $\mathrm{Zn}, \mathrm{Mn}$, and $\mathrm{Pb}$ ) [25]. Divalent metal transporter 1 represents a large family of metal ion transporters that are highly conserved from bacteria to humans [8]. The results of this study indicated that $\mathrm{Cu}$ from TBCC or CS has different effects on Mn metabolism. However, the mechanisms of the influence on metabolism of $\mathrm{Zn}$ and $\mathrm{Mn}$ by these $2 \mathrm{Cu}$ sources need further research.

The $\mathrm{Cu}$ contents of pigs' feces are largely a reflection of the 
concentration in the feeds consumed by the pigs. Studies showed that pigs absorbed only about $5 \%$ to $10 \%$ dietary $\mathrm{Cu}$ or even less [26]. Therefore, a high level of $\mathrm{Cu}$ will be excreted through the feces, which would result in excessive accumulation of $\mathrm{Cu}$ in the soils where the manure is applied and enrichment of $\mathrm{Cu}$ in plants that might induce a potential health risk to livestock or humans $[27,28]$. From the results of this study, we found that the concentrations of $\mathrm{Cu}$ in feces sharply decreased from $1,064 \mathrm{mg} / \mathrm{kg} \mathrm{DM}$ to $259 \mathrm{mg} / \mathrm{kg} \mathrm{DM}$ from $\mathrm{d} 0$ to 3 when the supplemental levels of $\mathrm{Cu}$ in the diets changed from $130 \mathrm{mg} / \mathrm{kg}$ to $10 \mathrm{mg} / \mathrm{kg}$. Copper contents in feces had already exceeded the maximum permitted limit of $\mathrm{Cu}(250$ $\mathrm{mg} / \mathrm{kg}$ ) in China [29]. Residues of $\mathrm{Cu}$ in manures can accumulate in surface soils, which could increase the risk of $\mathrm{Cu}$ contamination in the environment [30]. Recent research found that applications of pig manure containing high doses of $\mathrm{Cu}$ may lead to enrichment of $\mathrm{Cu}$ in brown rice and have potential long-term health risks through the food chain [31]. Excessive exposure to $\mathrm{Cu}$ has been linked to cellular damage in humans [32]. From the aspects of environmental protection and the safety of livestock and humans, Cu levels in animal feed should be controlled based on the relevant legal limits in China. According to Chinese regulation, $\mathrm{Cu}$ level in piglets, growing and finishing pigs which BWs were less than 30,30 to 60 and greater than $60 \mathrm{~kg}$, are not allowed to exceed the maximum permitted limit level 200, 150,35 mg/kg, respectively. Therefore, the results of this experiment reminded us that as more $\mathrm{Cu}$ was added to the diet, the amount accumulated in organs and the amount excreted by the animal also increased with both copper sources, SC and TBCC. So, to avoid the potential adverse effects of a high level of $\mathrm{Cu}$ on the characteristics of animal products and ecological environment, it is important to use only the recommended dietary levels of $\mathrm{Cu}$ in swine production.

In conclusion, the present experiment suggested that TBCC had no significant difference on growth performance but had higher activities of AST, ceruloplasmin and SOD than CS in growing pigs when pigs were fed diets with $130 \mathrm{mg} \mathrm{Cu} / \mathrm{kg}$ diet for $30 \mathrm{~d}$. At the same time, TBCC led to a lower accumulation of $\mathrm{Cu}$ in the liver of growing pigs than CS when diet was supplemented with $130 \mathrm{mg} / \mathrm{kg} \mathrm{Cu}$ for $81 \mathrm{~d}$. Cu concentrations in feces were significantly influenced by the concentration of $\mathrm{Cu}$ in both TBCC and CS diets.

\section{CONFLICT OF INTEREST}

We certify that there is no conflict of interest with any financial organization regarding the material discussed in the manuscript. Luo C and Wang S are employees of Chengdu Shuxing Feed Co. Ltd company.

\section{ACKNOWLEDGMENTS}

This study was founded by the earmarked fund from the China Pig Modern Industrial Technology System Grant (CARS-35) and the Science and Technology Support Program of Sichuan Province (2016NZ0006).

\section{REFERENCES}

1. NRC. Nutrient requirements of swine, eleventh rev.ed. Washington, DC, USA: National Academy Press; 2012.

2. Coble KF, DeRouchey JM, Tokach MD, et al. The effects of copper source and concentration on growth performance, carcass characteristics, and pen cleanliness in finishing pigs. J Anim Sci 2017;95:4052-9.

3. Braude R. Copper as a stimulant in pig feeding. World Rev Anim Prod 1967;3:69-82.

4. China GB. Tolerance limit of copper in foods. Beijing, China: China Standards Press; 1994.

5. Park CS, Kim BG. In vitro solubility of copper (II) sulfate and dicopper chloride trihydroxide for pigs. Asian-Australas J Anim Sci 2016;29:1608-15.

6. Feldpausch JA, Amachawadi RG, Scott HM, et al. Effects of added copper and zinc on growth performance and carcass characteristics of finishing pigs fed diets with or without ractopamine $\mathrm{HCl}$. Kansas, USA: Kansas Agricultural Experiment Station Research Reports; 2015;1:7. doi:10.4148/2378-5977.1134

7. AOAC. Official methods of analysis. 16th edition. Association of Official Analytical Chemists. Washington, DC, USA: AOAC International; 1995.

8. Cellier M, Privé G, Belouchi A, et al. Nramp defines a family of membrane proteins. Proc Natl Acad Sci USA 1995;92:1008993.

9. Hill GM, Cromwell GL, Crenshaw TD, et al. Growth promotion effects and plasma changes from feeding high dietary concentrations of zinc and copper to weanling pigs (regional study). J Anim Sci 2000;78:1010-6.

10. Clegg MS, Keen CL, Lönnerdal B, Hurley LS. Influence of ashing techniques on the analysis of trace elements in animal tissue. Biol Trace Elem Res 1981;3:107-15.

11. Cromwell GL, Lindemann MD, Monegue HJ, Hall DD, Orr DE Jr. Tribasic copper chloride and copper sulfate as copper sources for weanling pigs. J Anim Sci 1998;76:118-23.

12. Ronald L, Koretz MD. Chronic hepatitis: science and superstition. Cur Hepatol 1992;12:53-74.

13. He J, Zhang KY, Chen DW, et al. Effects of maize naturally contaminated with aflatoxin $\mathrm{B} 1$ on growth performance, blood profiles and hepatic histopathology in ducks. Livest Sci 2013; 152:192-9.

14. Sokol RJ, Devereaux M, Mierau GW, Hambidge KM, Shikes $\mathrm{RH}$. Oxidant injury to hepatic mitochondrial lipids in rats with dietary copper overload modification by vitamin $\mathrm{E}$ deficiency. 
Gastroenterology 1990;99:1061-71.

15. Pu J, Tian G, Li B, et al. Trace mineral overload induced hepatic oxidative damage and apoptosis in pigs with long-term highlevel dietary mineral exposure. J Agric Food Chem 2016;64: 1841-9.

16. Yang F, Friedrichs W, deGraffenried L, et al. Cellular expression of ceruloplasmin in lung: Antioxidant role. Am J Res Cell Mol 1996;14:161-9.

17. Gaetke LM, Chow CK. Copper toxicity, oxidative stress, and antioxidant nutrients. Toxicology 2003;189:147-63.

18. Obrosova IG, Stevens MJ. Effect of dietary taurine supplementation on GSH and NAD (P)-redox status, lipid peroxidation, and energy metabolism in diabetic precataractous lens. Invest Ophthalmol Vis Sci 1999;40:680-8.

19. Huang GJ, Deng JS, Huang SS, et al. Protective effect of antrosterol from antrodia cam phorata submerged whole broth against carbon tetrachloride-induced acute liver injury in mice. Food Chem 2012;132:709-16.

20. Huang YL, Ashwell MS, Fry RS, et al. Effect of dietary copper amount and source on copper metabolism and oxidative stress of weanling pigs in short-term feeding. J Anim Sci 2015;93: 2948-55.

21. Miles RD, O'Keefe SF, Henry PR, Ammerman CB, Luo XG. The effect of dietary supplementation with copper sulfate or tribasic copper chloride on broiler performance, relative copper bioavailability, and dietary prooxidant activity. Poult Sci 1998; 77:416-25.

22. Fry RS1, Ashwell MS, Lloyd KE, et al. Amount and source of dietary copper affects small intestine morphology, duodenal lipid peroxidation, hepatic oxidative stress, and mRNA expression of hepatic copper regulatory proteins in weanling pigs. J Anim Sci 2012;90:3112-9.

23. Araya M, Pizarro F, Olivares M, Arredondo M, Gonzalez M. Understanding copper homeostasis in humans and copper effects on health. Biol Res 2006;39:183-7.

24. Antonyuk SV, Strange RW, Marklund SL, Hasnain SS. The structure of human extracellular copper-zinc superoxide dismutase at $1.7 \mathrm{~A}$ resolution: Insights into heparin and collagen binding. J Mol Biol 2009;388:310-26.

25. Garrick MD, Dolan KG, Horbinski C, et al. DMT1: A mammalian transporter for multiple metals. Biometals 2003;16: 41-54.

26. Jondreville C, Revy PS, Dourmad JY. Dietary means to better control the environmental impact of copper and zinc by pigs from weaning to slaughter. Livest Prod Sci 2003;84:147-56.

27. Li L, Xu Z, Wu J, Tian G. Bioaccumulation of heavy metals in the earthworm Eisenia foetida in relation to bioavailable metal concentrations in pig manure. Bioresour Technol 2010; 101:3430-6.

28. Qureshi A, Lo KV, Liao PH, Mavinic DS. Real-time treatment of dairy manure: implications of oxidation reduction potential regimes to nutrient management strategies. Bioresour Technol 2008;99:1169-76.

29. China GB 4284-84. Control standards for pollutants in sludges fromagricultural use. Beijing, China: China Standards Press; 1984.

30. Guan TX, He HB, Zhang XD, Bai Z. Cu fractions, mobility and bioavailability in soil-wheat system after $\mathrm{Cu}$-enriched livestock manure applications. Chemosphere 2011;82:215-22.

31. Shi J, Yu X, Zhang M, et al. Potential risks of copper, zinc, and cadmium pollution due to pig manure application in a soil-rice system under intensive farming: a case study of Nanhu, China. J Environ Qual 2011;40:1695-704.

32. Tchounwou PB, Newsome C, Williams J, Glass K. Copperinduced cytotoxicity and transcriptional activation of stress genes in human liver carcinoma cells. Mol Cell Biochem 2004; 255:161-70. 